\title{
How did they make it? An examination of online personal branding: A pitch
}

\author{
Charlane Wonga, ${ }^{\mathrm{a}}$ \\ a University of Queensland, Australia
}

\begin{abstract}
A bstract: This paper applies Faff (2017)'s pitching template to an academic research topic in marketing. Specifically, I will provide a reflection on the use of this pitching template and encourage other academic researchers to utilize this template for their research topics.
\end{abstract}

K eywords: Pitching Research; Marketing; Branding

\section{J EL codes: M31; M37}

\section{Introduction}

This paper applies the pitching research template developed by Faff (2017) to an academic research topic in marketing. In relation to my academic background, I am currently studying the PhD program at the University of Queensland within the marketing cluster. I just started my program in J uly 2016. I was introduced to the pitching template at the initial stage of my research so I was very excited to do this exercise. This was because I was sure that this pitching research template would make my research very concise I encountered the concept of pitching research while I undertook Robert Faff's 'RBUS6914 - Process of Research in Business' coursework during the first semester of my PhD program I completed the pitch on my research for my advisors during one of our initial meetings. It took roughly about 20 hours to complete the pitching research template. This is where the pitching research templateincluded key literature, criticism and discussions.

\footnotetext{
${ }^{1}$ Corresponding author: UQ Business School, The University of Queensland, Colin Clark, 39 Blair Dr, St Lucia QLD 4067; tel. (+61) (07) 3346 8100; Email addresses: charlanewong@business.uq.edu.au
} 
Before this pitching research template, I initially produced another pitching template for my PhD application. Therefore, I had a brief idea on how to complete the pitching research template where I completed each part of the template step by step according to the template's format. This pitch is for my own real piece of research that I intend to execute for $\mathrm{my} \mathrm{PhD}$ program This paper will provide a brief overview on how I have completed the pitching research template followed by a personal reflection on it as well as concluding comments.

\section{B rief commentary on the pitch}

The pitching research template is summarized in Table 1 where my basic research question is "What are the constructs that contribute to the success of online personal branding?' The research idea stems from the process of creating an onl ine personal brand and specifically to discover what influences online personal branding success and how to maintain this particular success. The key paper is Lam et al. (2010)'s paper on Customer Based Identification. The motivation or puzzle of my research interest comes from the view that every consumer is a human brand and therefore has the opportunity to use this brand to create their own customer base and equity anal ogous to product brands. The motivation for this research is to discover the constructs and theories that explain online personal branding. Social media has been a recent and popular phenomenon in which consumers have been engaging. This is where they have used social media to communicate and retrieve information.

During the process of completing this pitching research template, I found it extremely difficult to complete several sections. These sections indude 'The Basic Research Question', 'Motivation', 'Idea', 'What's new', 'So what and 'Contribution'. This was because my PhD program was just at the initial stage, there was a lot of uncertainty as I had only just started to read into the literature. This is where I was still exploring 'What was new' and 'What was done' within my field of research. When it came to my key paper for my pitching research template, it was very hard to provide only one paper as there were many papers that were relevant. Therefore, it took me a long while to decide which paper to include as my key paper for my pitching research template.

The most difficult part out of the whole pitching research template was the 'Contribution' and 'What's new' section. This was becausel found both sections to be extremely similar. But after analyzing both sections in relation to my research interest, I eventually realized both sections are not the same. This was because 'What's new' does not necessarily mean it has contribution towards the academic literature. Good quality research doesn't necessarily mean to fill gaps within the literature for the sake of gap spotting (Alvesson \& Sandberg, 2013) but it is instead 
to have quality research that has an impact and contribution towards the relevant academic literature In addition, I al so examined and reviewed several examples of other pitching research templates in order to know what to expect within the content of each section. After my reviews, I then created a more organized draft for my pitching research template.

On the other hand, I thought three sections within the pitching research templ ate to be quite straightforward. These include 'Data', 'Tools' and 'Other Considerations'. After I have completed my pitching research template, I have real ized this template is essential for my future research decisions as this research template really made my research concise. Essentially, this pitching research template asks the most important questions and showcases the essence of my research.

\section{Personal reflection}

It has been a worthwhile exercise transforming my research ideas into a pitching research template developed by Faff (2015). As a PhD student, I was facing a lot of uncertainty and challenges to consolidate my research ideas into a standard pitching research template. This tool really helped my thoughts and ideas for my research project in a systematic way leading me to be concise and in the right direction. This is where this pitching research template asks the most important questions such as 'What's new' and 'So what' in relation to my research. In addition to the efficiency of this tool, this template also hel ped me to identify the strengths and weakness of my research. This led to me as a researcher to be able to understand the strengths of my research as well as acknowl edge the weaknesses in order prepare for constructive criticismin the future.

Additionally, the 'Mickey Mouse' diagram which relates to pitching research as shown in Figure 1 was al so a very crucial tool to highl ight my research idea. Figure 1 showcases the "Mickey Mouse" diagram for my research project. This is where this diagram highlights the top three most important areas of my research project.

Prior to my PhD admission, I never thought there was a pitching research template. If I knew about the pitching research template during my honours degree, I think it would have definitely benefited me as I would have had a much clearer direction with my honours research project then. Therefore, I am very happy to have come across this tool during my beginning phase of my PhD program since it will challenge me to think what is my actual research project about. This is where, in time, I could potentially have the ability to publish my research with a positive contribution within the academic literature. 
Table 1. C ompleted 2-page pitch template on online personal branding

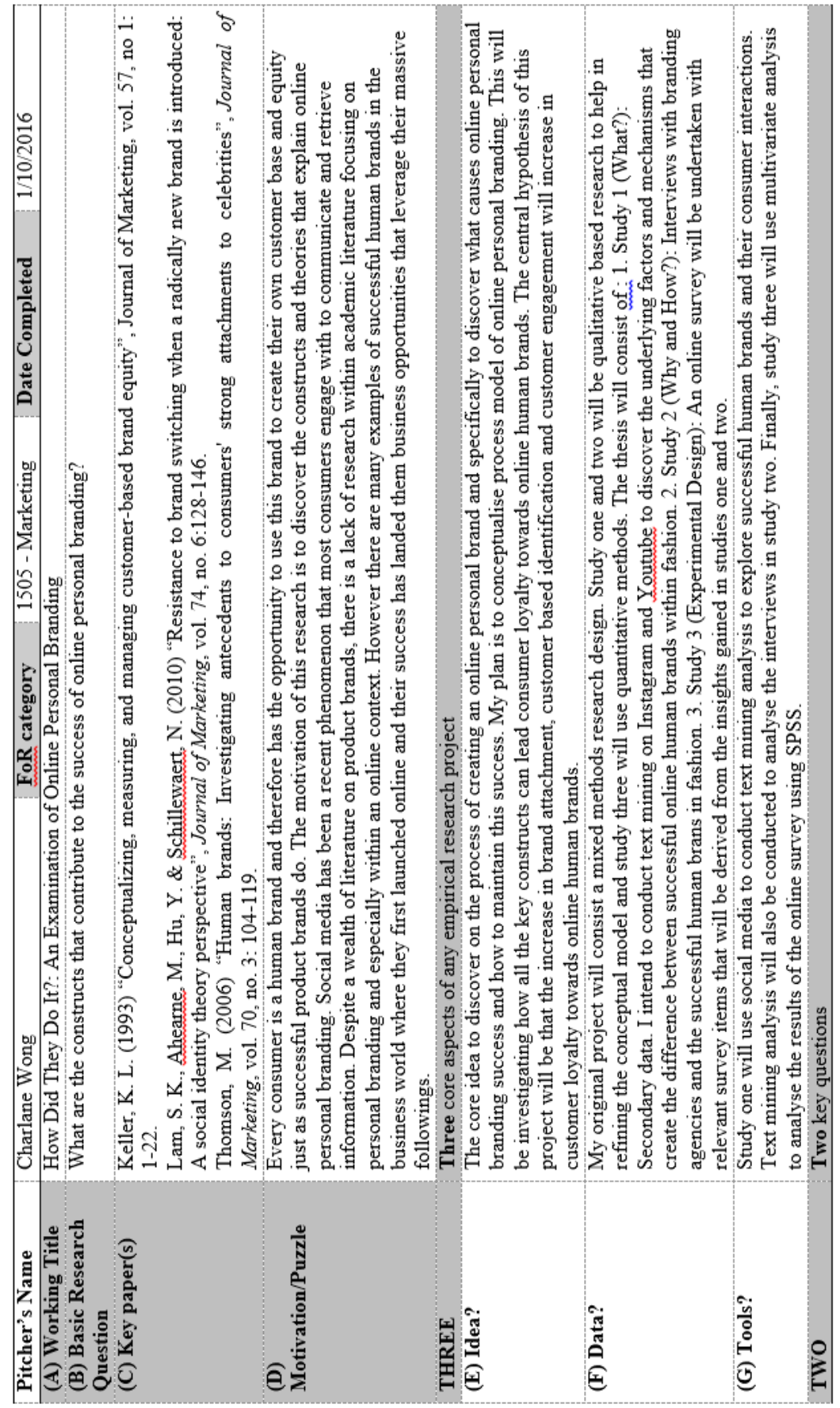




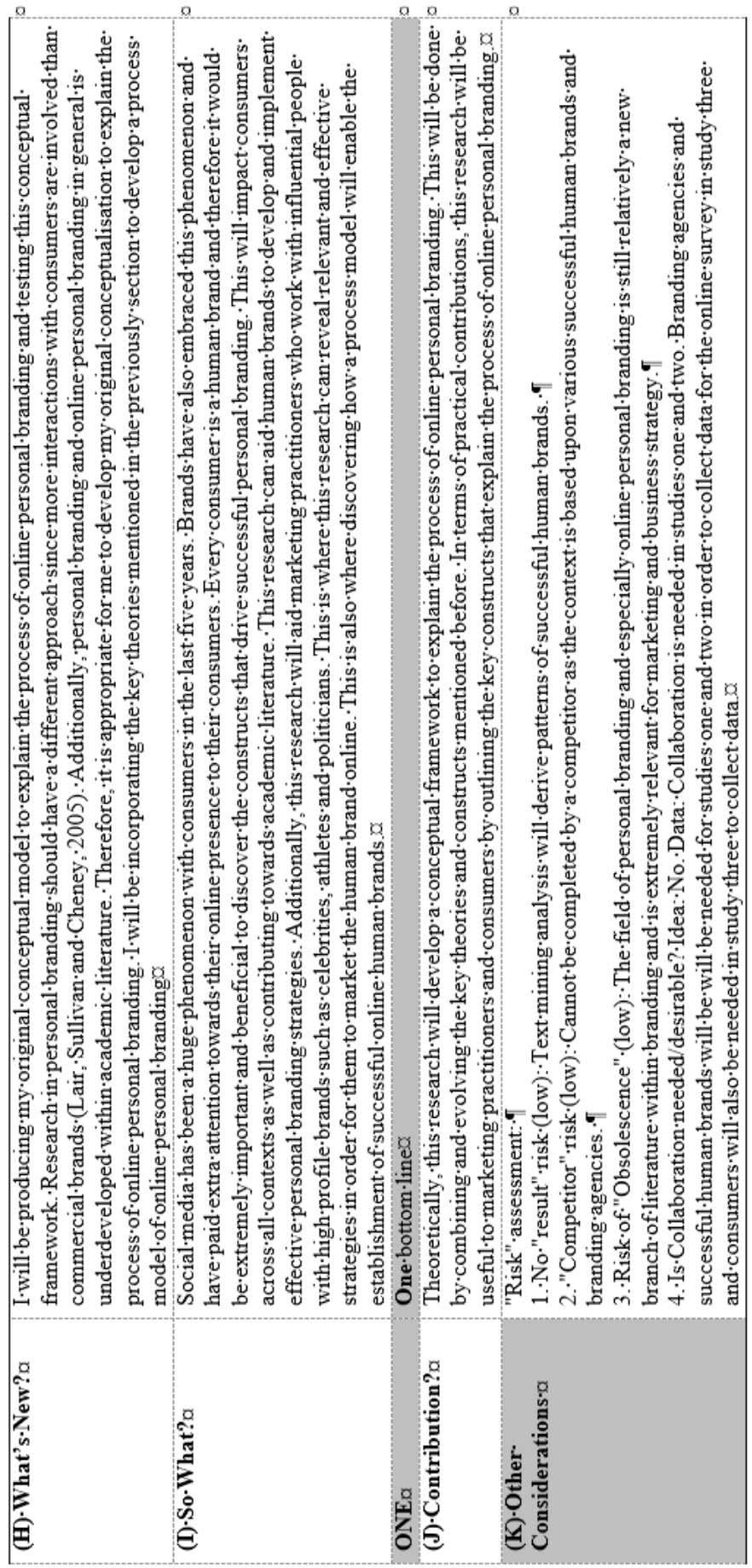

Vol. 16, No. 3 


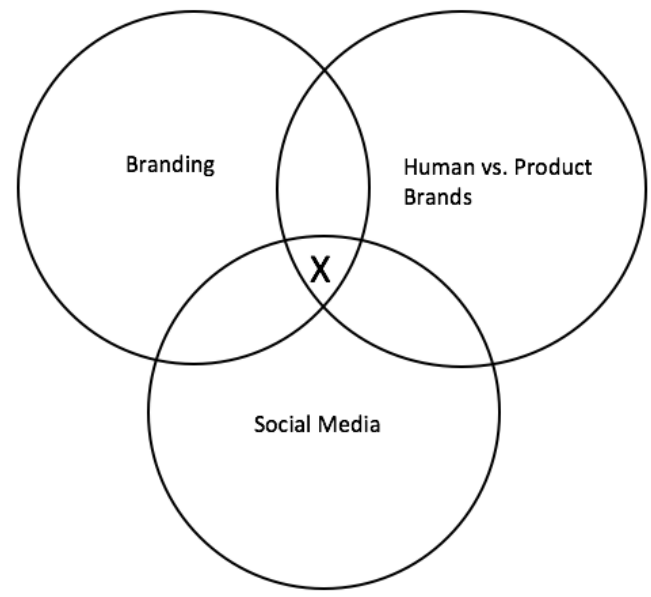

Figure 1. M ickey M ouse diagram characterizing novelty of research idea

\section{Concluding remarks}

This short paper showcases a commentary and a self-reflection of the pitching research template applied within marketing which aims to discover the drivers towards successful online human brands. It should be emphasized that the pitching research template is a great resource for novice academic researchers. This is where they will face many uncertainties and difficulties during their beginning phases of their academic career. This tool can al so aid experienced researchers as it can provide a standard format to showcase their research. Faff (2015)'s pitching research template format is quite straightforward to apply for any research area. Different researchers from areas of research can adapt this template into their research projects. Hence, I strongly encourage any academic researcher to implement this pitching research template within their academic research experience.

\section{References}

Alvesson, M. \& Sandberg, J. (2013) Constructing research questions: Doing interesting research, Sage

Faff, R. (2017) "Pitching Research", Available at SSRN: http://ssrn.com/abstract=2462059

Keller, K. L. (1993) "Conceptualizing, measuring, and managing customer-based brand equity", J ournal of Marketing, vol. 57, no.1: 1-22 
Lam S. K., Ahearne, M., Hu, Y. \& Schillewaert, N. (2010) "Resistance to brand switching when a radically new brand is introduced: A social identity theory perspective", J ournal of Marketing, vol. 74, no. 6: 128-146

Rahman, D. M. (2016) "Investor Sentiment, Executive Compensation, and Investment-Some International Evidence: A Pitch", Accounting and Management Information Systems, vol. 15, no. 2: 428-433

Thomson, M. (2006) "Human brands: Investigating antecedents to consumers' strong attachments to celebrities", J ournal of Marketing, vol. 70, no. 3: 104-119

Wallin, A. \& Spry, A. (2016) "The role of corporate versus product brand dominance in brand portfolio overlap: A Pitch", Accounting and Management Information Systems, vol. 15, no. 2: 434-439 